\title{
Glycodelin mRNA is expressed in the genital tract of male and female rats (Rattus norvegicus)
}

\section{Ch Keil, B Husen ${ }^{1}$, J Giebel ${ }^{1}$, G Rune ${ }^{1}$ and R Walther}

\author{
Institute of Biochemistry, Ernst Moritz Arndt University, Klinikum, Sauerbruchstrasse, \\ D-17487 Greifswald, Germany \\ ${ }^{1}$ Institute of Anatomy, Ernst Moritz Arndt University, Friedrich Loeffler Strasse 23c, \\ D-17487 Greifswald, Germany
}

(Requests for offprints should be addressed to R Walther)

\begin{abstract}
In the present study we demonstrate for the first time the expression of glycodelin mRNA in the female and male genital tracts of rats using non-radioactive in situ hybridisation. Glycodelin fragment $1(+41$ to +141$)$ shares $100 \%$ homology with the human gene sequence. In the ovary, glycodelin mRNA was restricted to granulosa cells. In the uterus, glycodelin mRNA was expressed in all epithelial cells of the endometrium. In the male reproductive tract, glycodelin mRNA was
\end{abstract}

distributed in all epithelial cells of the epididymis, the prostate and the seminal vesicle. However, in the testis, glycodelin mRNA was predominantly found in spermatogonia and in spermatocytes of the seminiferous epithelium. The expression in several reproductive organs of rats offers an excellent tool to study further the physiological role of glycodelin, which is so far thought to act as an immunosuppressive factor.

Fournal of Molecular Endocrinology (1999) 23, 57-66

\section{INTRODUCTION}

Glycodelin (Dell et al. 1995), formerly known as placental protein 14 (PP14) is a $28 \mathrm{kDa}$ glycoprotein containing $17 \cdot 5 \%$ carbohydrates (Bohn et al. 1982). This protein is characterised by immunosuppressive and contraceptive properties (Bolton et al. 1987, Oehninger et al. 1995). Although it is expressed in organs of the male as well as the female human genital tract, the glycosylation of this protein is sex dependent. Glycodelin A $(\mathrm{GdA})$, which originated from amniotic fluid, contains many mannose residues, whereas glycodelin $\mathrm{S}(\mathrm{GdS})$, which was isolated from seminal plasma, is rich in fucose residues (Morris et al. 1996). Unlike GdA, GdS exhibits no contraceptive activity (Morris et al. 1996). In women, expression of glycodelin mRNA was found in glandular epithelial cells of the secretory endometrium (Julkunen et al. 1986b). Furthermore it was detected in epithelial cells of the Fallopian tube (Julkunen et al. 1986c) in vivo as well as in cultures of these cells (Saridogan et al. 1997). Although the synthesis of glycodelin is so far thought to be restricted to these two organs the protein was also immunologically detected in ovary (Kämäräinen et al. 1996), follicular fluid (Chryssikopoulos et al. 1996) and amniotic (Julkunen et al. 1985) and uterine luminal fluid (Bell \& Doré-Green 1987), as well as in plasma (Julkunen et al. 1986a). The glycodelin plasma levels are dependent on the stage of the menstrual cycle and it was shown that they were highest during the late secretory phase (e.g. the late luteal phase of the ovulatory cycle) and even during the first days of the next cycle (Julkunen et al. 1986a). In the human male genital tract, glycodelin mRNA was detected in epithelial cells of the seminal vesicle and the ampulla of the vas deferens (Julkunen et al. 1984, Koistinen et al. 1997). Recent studies revealed evidence for the existence of different glycodelin mRNA splice forms in humans (male individuals: Koistinen et al. 1997, female individuals: Garde et al. 1991) and in megakaryocyte cell lines (Morrow et al. 1994). The glycodelin protein, however, was detected in high concentrations in the seminal plasma (Julkunen et al. 1984). In the present study we show for the first time the expression of glycodelin mRNA in the rat using non-radioactive in situ hybridisation. Furthermore we demonstrate that rat glycodelin fragment 1 shares a $100 \%$ homology with the human gene sequence. 


\section{MATERIALS AND METHODS}

\section{Preparation of tissue RNA and cDNA}

Rat tissues (Rattus norvegicus, Lewis 1A, uterus, ovary testis and liver) as well as human decidua tissue (obtained from early abortions from the Institute of Obstetrics and Gynaecology, University of Greifswald) were homogenised with an UltraTurrax T25, Janke \& Kunkel, Germany. Total RNA was isolated using guanidinium-isothiocyanate (RNeasy Midi Kit, Qiagen, Hilden, Germany), digested with DNase I for $1 \mathrm{~h}$ at $37^{\circ} \mathrm{C}$ and translated into cDNA by reverse transcription PCR with oligodT-primers and Superscript II (Gibco-BRL, Life Technologies, Eggenstein, Germany).

\section{Synthesis of digoxigenin (DIG)-labelled cRNA probes}

Specific primers for glycodelin (PP14-pBSK-for: 5'-AGCCATGCTGTGCCTCCTGCTCA-3'; PP14pBSK-rev: 5'-ACGATCTCCAGGTTGTCCTC-3') were designed according to the known human sequence of glycodelin as described by Julkunen et al. (1988). Using reverse transcription PCR (RT-PCR) a $227 \mathrm{bp}$ fragment of the coding sequence of glycodelin (position +41 to +268 ) was amplified from decidua cDNA. This fragment was cloned into the EcoRI site of the cloning vector pBSK (minus) and translated in cRNA by in vitro transcription and labelled with DIG using the DIG RNA Labelling Kit (SP6/T7) (Boehringer, Mannheim, Germany). The antisense cRNA was used for the detection of glycodelin mRNA whereas the sense cRNA probe was used as a negative control.

\section{Tissue specimens from rats}

Samples from male/female rats (Lewis 1A) were obtained from the Institute of Pathophysiology, University of Greifswald. Animals were killed by an overdose of thiopental and samples removed quickly and frozen in liquid nitrogen. Tissue samples from lung, liver and kidney were processed in the same way as samples from the genital tract and used as controls. Cryostat sections $(8 \mu \mathrm{m})$ were fixed in $4 \%$ paraformaldehyde $(15 \mathrm{~min})$, washed twice in PBS (pH 7.4) and dehydrated in 70 and 96\% ethanol. The sections were stored in $96 \%$ ethanol at $4{ }^{\circ} \mathrm{C}$ until used.

\section{Preparation of genomic DNA}

Genomic DNA was isolated from blood cells of the human and the rat according to the following protocol: $10 \mu \mathrm{l}$ blood were haemolysed with $400 \mu \mathrm{l}$ twice-distilled water and pelleted (10 $000 \boldsymbol{g}, 1 \mathrm{~min})$.
The pellet was washed three times in twice-distilled water and resuspended in $10 \mu \mathrm{l}$ fresh solution of $200 \mathrm{mM} \mathrm{KOH}$ and $50 \mathrm{mM}$ dithiothreitol (DTT). After incubation at $65{ }^{\circ} \mathrm{C}(15 \mathrm{~min})$ the solution was chilled on ice and supplemented with $10 \mu \mathrm{l}$ buffer $(900 \mathrm{mM}$ Tris, $300 \mathrm{mM} \mathrm{KCl}, 200 \mathrm{mM} \mathrm{HCl}$, $\mathrm{pH} 8 \cdot 3)$. The DNA was stored at $-20{ }^{\circ} \mathrm{C}$.

\section{PCR}

PCR (annealing temperature $68^{\circ} \mathrm{C}, 30$ cycles) was done using the glycodelin-specific primers PP14-for I(5'-CCGCTAGCTAAAGCTTAGCCATGCTG TGCCTCCTGCTCA-3') and PP14-ExonI-rev (5'-CCGATCACTTC'TCGAGCTTTGGGAGC TCCAGGTCCTGCTTGGTC-3'). The PCR products (100 bp, position +41 to +141$)$ were identified by agarose gel electrophoresis $(1 \cdot 5 \%)$. The fragments were subcloned into the $\mathrm{pCDM} 8$ vector using standard procedures.

\section{RT-PCR}

RT-PCR (annealing temperature $68^{\circ} \mathrm{C}, 30$ cycles) was done using the glycodelin-specific primers PP14-for I (5'-CCGCTAGCTAAAGCT'TAGC CATGCTGTGCCTCCTGCTCA-3') and PP14ExonIII-rev(5'GGATTCTCAGTCTTCTCTCC$\left.3^{\prime}\right)$. The PCR products were identified by agarose gel electrophoresis $(1 \cdot 5 \%)$.

\section{Southern blot}

In brief, DNA was separated using $1 \%$ agarose gel, subsequently denatured $(0.5 \mathrm{M} \mathrm{NaOH}, 1.5 \mathrm{M}$ $\mathrm{NaCl})$, neutralised $(0.5 \mathrm{M}$ Tris, $\mathrm{pH} 7.5 ; 1.5 \mathrm{M}$ $\mathrm{NaCl})$ and blotted by capillary blot $(20 \times \mathrm{SSC}$, see below) overnight on a positively charged nylon membrane. After fixation (UV light), DNA was prehybridised with DIG Easy Hyb solution (Boehringer), 2-12 h, $52{ }^{\circ} \mathrm{C}$, and hybridised with DIG-RNA probe $(1: 3000$ in DIG Easy Hyb solution, $52{ }^{\circ} \mathrm{C}$, overnight). Visualisation of bound probe was achieved using the chemiluminescent detection method (Boehringer).

\section{Sequencing}

DNA was sequenced using the T7 Sequenase version 2.0 DNA sequencing kit (Amersham Life Science, Cleveland, USA) according to the manufacturer's protocol.

\section{In situ hybridisation}

Sections (see above) were rehydrated and washed twice in PBS ( $\mathrm{pH} 7 \cdot 4)$. Sections were subjected to proteinase- $\mathrm{K}$ digestion $(10 \mu \mathrm{g} / \mathrm{ml}$, maximum $4 \mathrm{~min}$, 
$37^{\circ} \mathrm{C}$ ) and then rinsed with $0 \cdot 2 \%$ glycine. Sections were then post-fixed (paraformaldehyde $4 \%, 5 \mathrm{~min}$, $\left.4{ }^{\circ} \mathrm{C}\right)$, treated with triethanolamine $(0 \cdot 1 \mathrm{M}, \mathrm{pH} 8 \cdot 0$, $3 \mathrm{~min}$ ) and acetylated using $0 \cdot 25 \%$ aceticanhydride in $0 \cdot 1 \mathrm{M}$ triethanolamine $(10 \mathrm{~min})$. After two washes for $2 \mathrm{~min}$ in $2 \times \mathrm{SSC}(1 \times \mathrm{SSC}$ : $150 \mathrm{mM}$ $\mathrm{NaCl}, 15 \mathrm{mM}$ sodium citrate, $\mathrm{pH} 7 \cdot 0$ ) sections were dehydrated in ethanol $(50,70,96,100 \%)$ and prehybridised in a solution containing dextran sulphate $(10 \%), 20 \times \operatorname{SSC}(5 \%)$ de-ionised formamide $(2 \cdot 5 \%)$, DTT $(10 \mathrm{mM})$, t-RNA $(0 \cdot 1 \mathrm{mg} / \mathrm{ml})$, $1 \times$ Denhardt-solution (Ficoll, polyvinylpyrrolidone, BSA) for $2 \mathrm{~h}$ at $42{ }^{\circ} \mathrm{C}$ in a humid chamber. Hybridisation with the DIG-labelled riboprobes $(160-500 \mu \mathrm{g} / \mathrm{ml}$ in prehybridisation buffer) was carried out overnight $(16-20 \mathrm{~h})$ on a hot plate $\left(42{ }^{\circ} \mathrm{C}\right.$ ). Sections were washed in $4 \times \mathrm{SSC}$ (once for $20 \mathrm{~min}$, twice for $5 \mathrm{~min}$ ) and subsequently incubated with RNase A $\left(10 \mathrm{mg} / \mathrm{ml}, 30 \mathrm{~min}, 37^{\circ} \mathrm{C}\right)$. After several washes in different $\mathrm{SSC}$ concentrations $(2 \times \mathrm{SSC}, 1 \times \mathrm{SSC}, 0 \cdot 5 \times \mathrm{SSC}, 0 \cdot 1 \times \mathrm{SSC})$ and a final wash in DIG-1 buffer $(0 \cdot 1 \mathrm{M}$ Tris-HCl, $0 \cdot 15 \mathrm{M} \mathrm{NaCl}, \mathrm{pH} 7 \cdot 5 ; 5 \mathrm{~min})$, sections were blocked in blocking buffer (blocking-reagent, Boehringer, 1:20 in DIG-1 buffer). Subsequently, sections were washed in DIG-1 buffer (twice for $10 \mathrm{~min}$ ) and incubated with an alkaline phosphatase-conjugated anti-DIG antibody (1:500 in blocking-buffer, $4 \mathrm{~h}$, $22{ }^{\circ} \mathrm{C}$, Boehringer). Visualisation of bound riboprobe was done after washes with DIG-1 buffer (twice for $10 \mathrm{~min}$ ) and DIG-2 buffer (DIG-1, pH 9.5; $10 \mathrm{~min})$ in DIG-2 buffer containing 5-bromo-4-chloro-3-indolyl phosphate/nitrobluetetrazolium chloride for $2-48 \mathrm{~h}$ in the dark.

\section{Northern blot}

In brief, total RNA was subjected to agarose gel electrophoresis $(1 \%$ agarose in morpholinopropanesulfonic acid-buffer, $1 \cdot 85 \%$ formaldehyde), blotted onto nylon membranes (capillary blot, overnight), UV crosslinked, prehybridised $\left(68^{\circ} \mathrm{C}\right.$, DIG Easy Hyb solution) and hybridised using the glycodelin cRNA-probe (diluted 1:3000 in DIG Easy Hyb solution, $68^{\circ} \mathrm{C}$, overnight). Visualisation was achieved as described above under RT-PCR. After visualisation, blots were rehybridised with $\beta$-actin cRNA probe (diluted 1:3000 in DIG Easy Hyb solution, $68^{\circ} \mathrm{C}$, overnight) and detected once again.

\section{RESULTS}

\section{The generated riboprobe detects glycodelin from different species}

A part of the first glycodelin exon (100 bp; position +41 to +141 ) was amplified by PCR using the
PP14-for I and PP14-ExonI-rev primers and genomic DNA from human and rat respectively. In both cases fragments of expected size were obtained (Fig. 1A, lanes 2-4 respectively). By sequencing the subcloned fragment the identity of the nucleotide sequence of the obtained PCR fragments was confirmed (not shown). The sequence of the rat glycodelin fragment revealed 100\% homology with the human gene sequence. In Southern blots the human $227 \mathrm{bp}$ cRNA (position +41 to +268) antisense probe was suitable to detect glycodelin PCR fragments from genomic DNA of different species (Fig. 1B).

\section{In situ hybridisation experiments in female reproductive organs}

In rats, glycodelin mRNA was localised in the ovary and the uterus. Granulosa cells of follicles of all developmental stages expressed glycodelin. In antral follicles all granulosa cells were stained (Fig. 2B). In preantral follicles granulosa cells neighbouring the basement membrane were more strongly stained compared with granulosa cells close to the follicular centre. The latter showed a faint expression of glycodelin mRNA (Fig. 2A). Atretic follicles were negative. Theca and stroma cells as well as corpora lutea cells were devoid of glycodelin mRNA. In the uterus, glycodelin mRNA was expressed in all epithelial cells of the endometrium. The staining of the luminal epithelial cells, however, was significantly stronger compared with epithelial cells of uterine glands (Fig. 2D).

\section{Male reproductive organs}

In the seminiferous epithelium of the testis, glycodelin mRNA was expressed in some spermatogonia and spermatocytes (Fig. 3A). The reaction was seen as an intense spot-like staining in the nucleus or the cytoplasm of the respective cells. In the epididymis, glycodelin mRNA was localised in all cell types of the epithelium, i.e. principal cells, basal cells and apical cells (Fig. 3C). In the prostate, as well as in the seminal vesicle, all glandular epithelial cells expressed glycodelin (Fig. 4A and C).

\section{Controls}

All sections which were incubated with the respective sense probes were devoid of any reaction (Figs 2C and E, 3B and D, 4B and D). For further testing of the specificity of the antisense probe, in situ hybridisation experiments were done on frozen sections of rat liver, lung and kidney. These tissues showed no staining with the glycodelin mRNA antisense probe. 
A

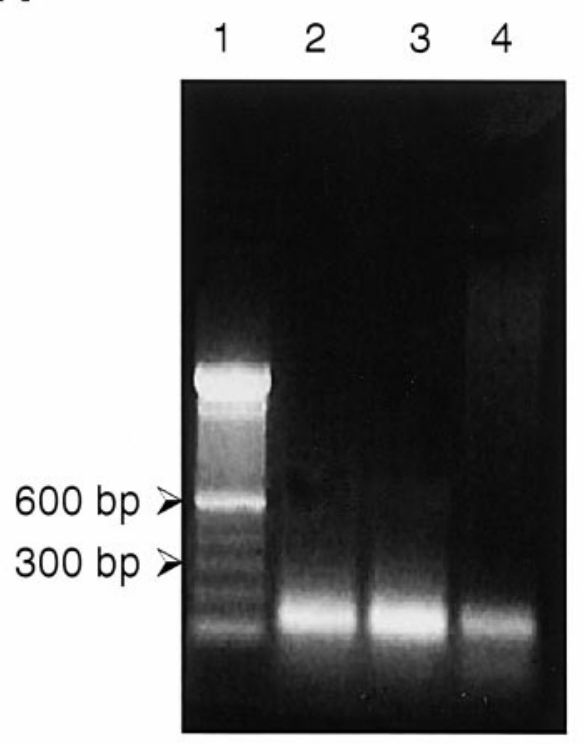

B

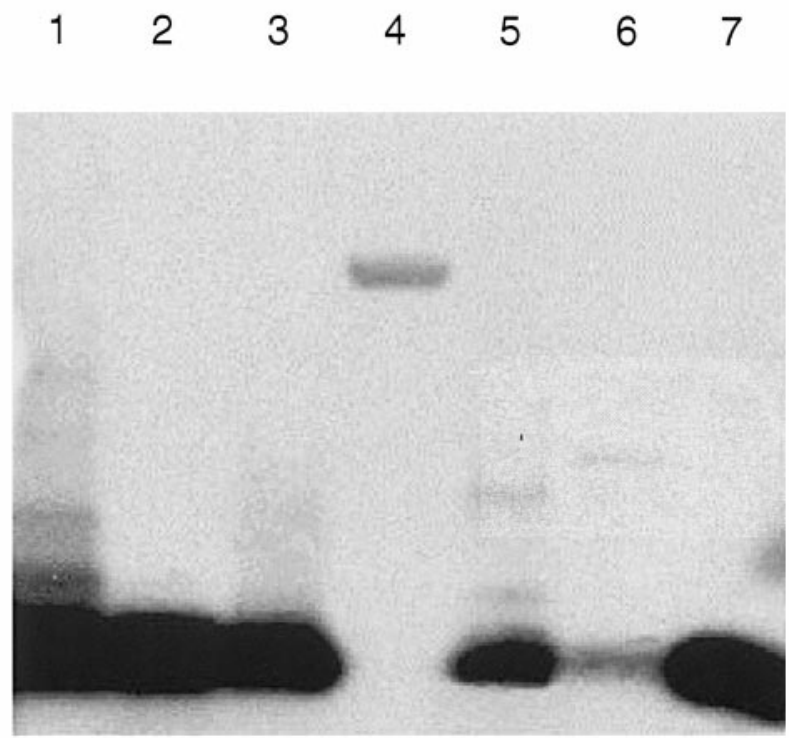

FIGURE 1. (A) PCR of glycodelin. $100 \mathrm{bp}$ ladder (lane 1); rat genomic DNA (lanes 2 and 3); human genomic DNA (lane 4). (B) Southern blot of PCR fragments hybridised with glycodelin antisense probe. Human (lane 1), pig (lane 2), sheep (lane 3), $100 \mathrm{bp}$ ladder (unlabelled, lane 4), rat (lane 5), mouse (lane 6), dog (lane 7).

\section{RT-PCR of different rat tissues (organs)}

RT-PCR was done in some selected tissues to confirm the results obtained by in situ hybridisation. It turned out that glycodelin mRNA is expressed in uterus, ovary and testis. The amplified product had a size of approximately $300 \mathrm{bp}$. Control RT-PCRs conducted with liver cDNA and total RNA from uterus, ovary and testis were negative (Fig. 5).

\section{Northern blotting of different rat tissues (organs)}

Northern blots were done with RNA isolated from some selected tissues to demonstrate the specificity of the generated cRNA probe. Glycodelin mRNA was detected in ovary and testis but not in liver (Fig. 6A). Glycodelin mRNA could be detected also in uterus (not shown). Fig. 6B demonstrates positive blots of human decidua RNA, placental as well as decidua RNA from early pregnancy (abortion material) and term pregnancy decidua and placental RNA. The size of the human and rat mRNA was about $1 \mathrm{~kb}$. In all Northern blots a $\beta$-actin probe was used to ensure equal amounts of RNA.

\section{DISCUSSION}

In the present study glycodelin, which was formerly detected almost exclusively in humans, was shown for the first time to be expressed in reproductive organs of female as well as male rats. Furthermore, it was also shown that besides its well-established expression sites in humans (uterus, fallopian tube and seminal vesicle) glycodelin mRNA is also expressed in the ovary, the testis, the epididymis and the prostate of rats. In this study a human cRNA probe was generated using primers according to the known human glycodelin sequence as described by Julkunen et al. (1988) and Vaisse et al. (1990). Moreover, using human glycodelin exon 1 primers a glycodelin fragment was amplified from rat genomic DNA which shows a size identical to that of the human fragment. After sequencing it turned out that this rat glycodelin fragment was completely homologous to exon 1 of human glycodelin. Similar results were also obtained in our laboratory for pigs, cows, dogs and mice (Fig. 1B). In Northern blots it was shown that the rat and human glycodelin mRNA had a similar size. Thus we propose that glycodelin is a highly conserved glycoprotein in mammals.

These findings strongly suggest that glycodelin expression is of functional relevance in the reproductive tract of mammals. In the present study 

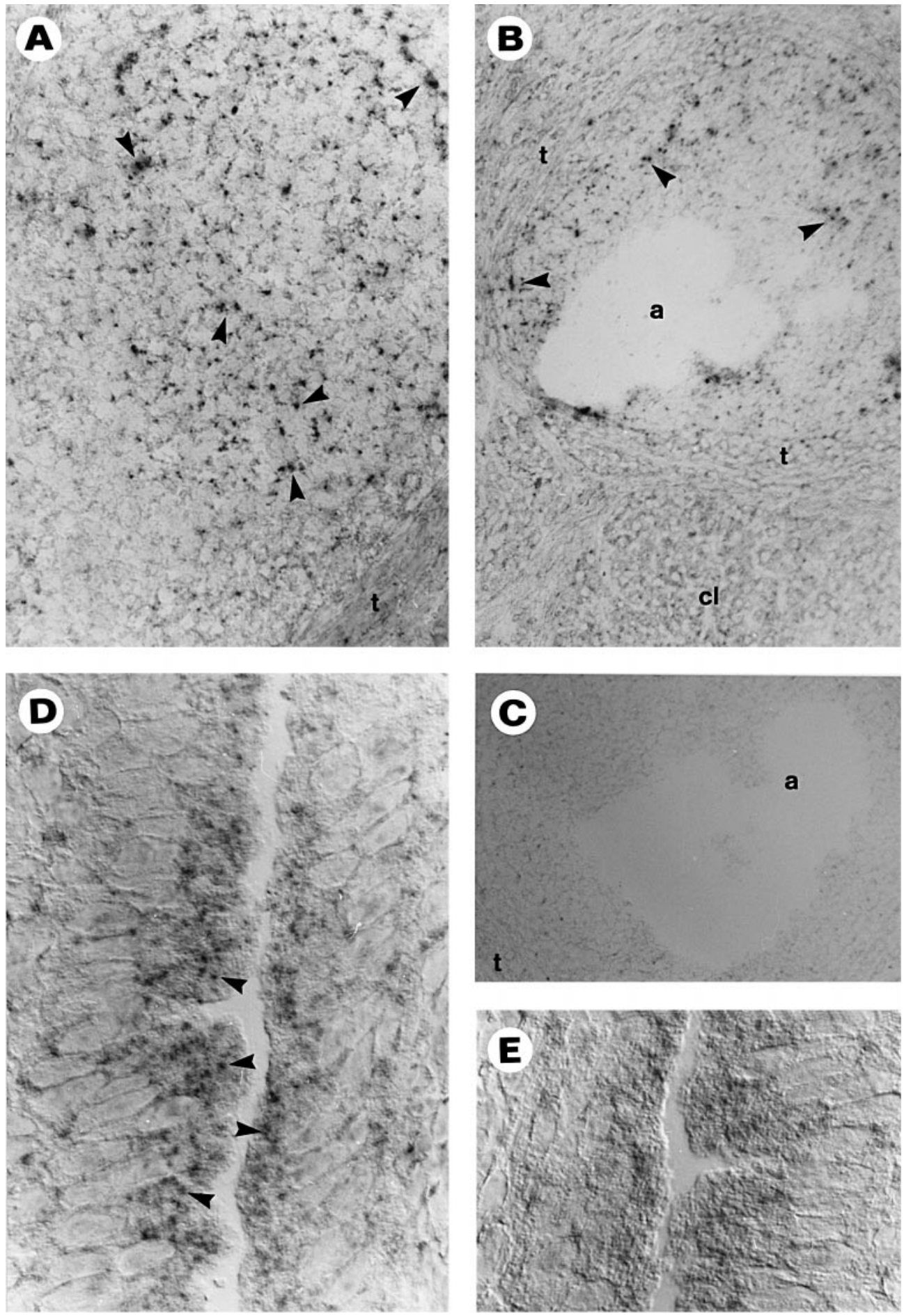

FIGURE 2. In situ hybridisation experiments of glycodelin mRNA probes in ovary and uterus of rats. (A) Preantral follicle and (B) antral follicle: the glycodelin expression is evident in granulosa cells (arrows) as an intense spot-like reaction, theca cells ( $\mathrm{t}$ ) and cells of the corpus luteum $(\mathrm{cl})$ were negative; a=follicular antrum. (D) Uterus: a positive reaction is seen at the apical pole of luminal epithelial cells of the endometrium (arrows). The control reactions (sense probe) are shown in $(\mathrm{C})$ and $(\mathrm{E})$. Magnification: $\mathrm{A}-\mathrm{C} \times 280$; D and $\mathrm{E} \times 560$. 

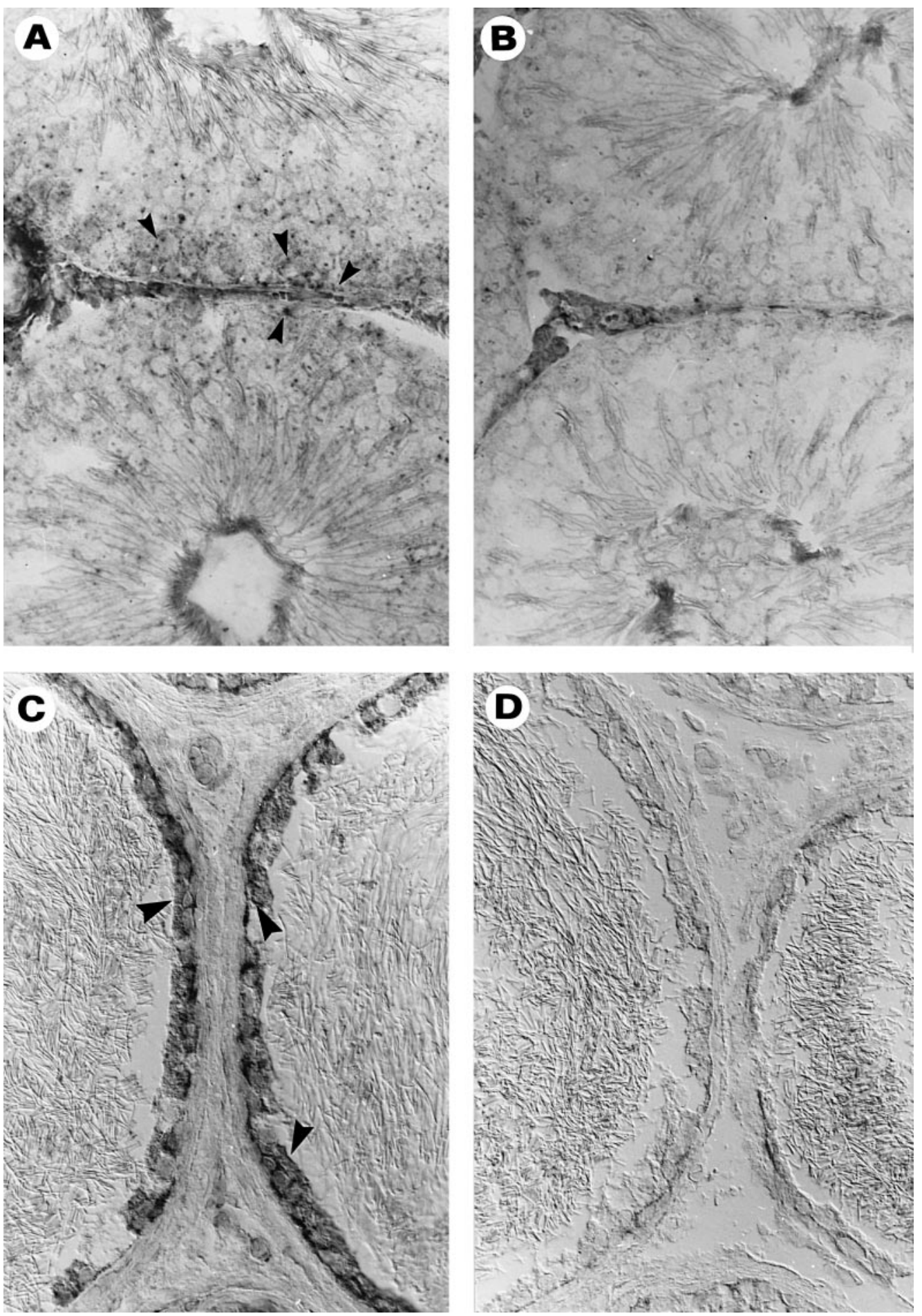

FIGURE 3. In situ hybridisation experiments of glycodelin mRNA probes in testis and epididymis. (A) Glycodelin expression (antisense probe) in the testis is evident as small spots in spermatogonia as well as in spermatocytes (arrows); note non-specific reaction at sperm heads and tails. (C) In the epididymis a strong positive reaction is distributed all over the cytoplasm of all epithelial cells (arrows). The control reactions (sense probe) are shown in (B) (testis) and (D) (epididymis). Magnification: $\times 280$. 

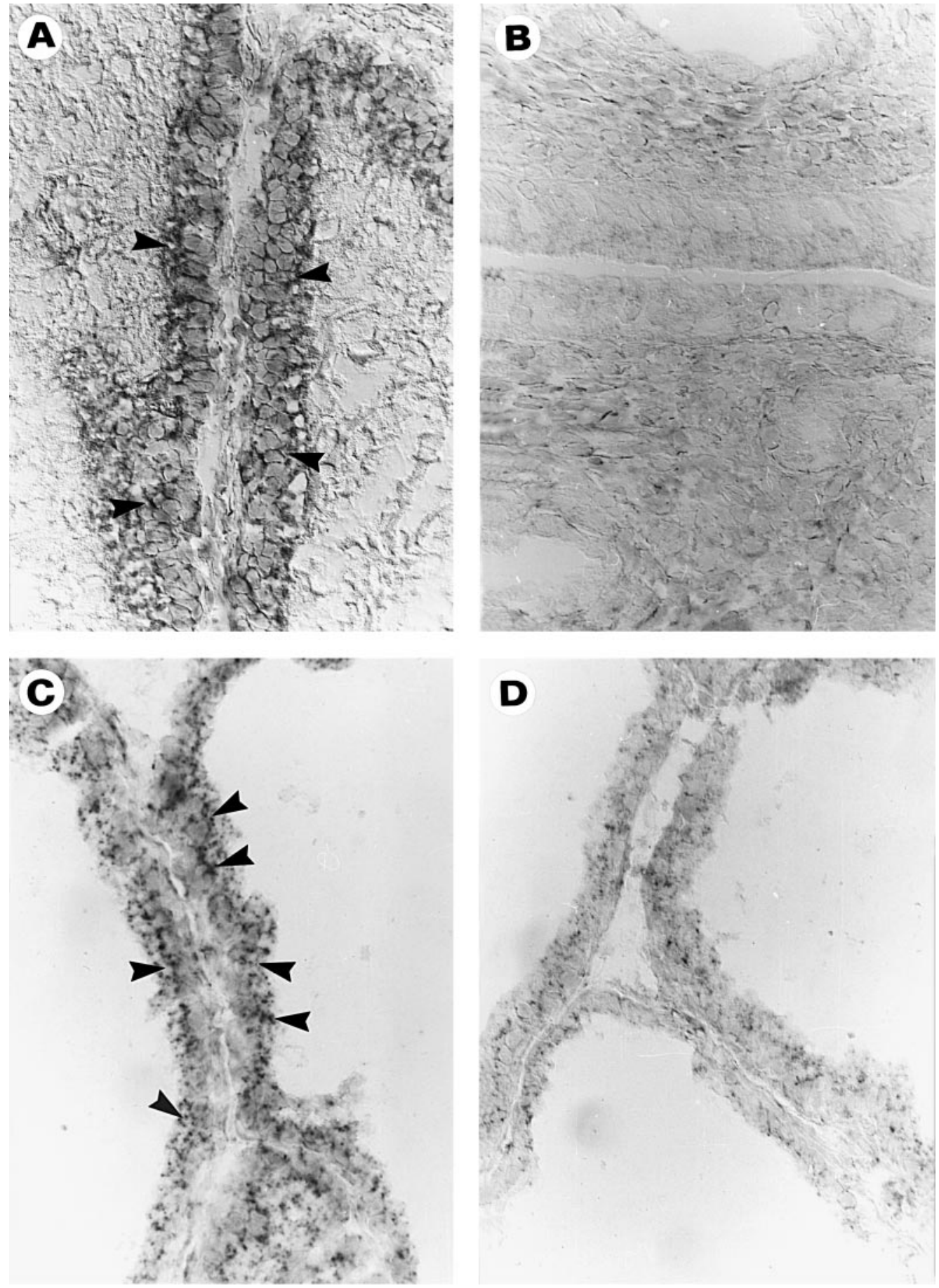

FIGURE 4. In situ hybridisation experiments of glycodelin mRNA probes in prostate and seminal vesicle. (A) Glycodelin expression (antisense probe) in the seminal vesicle is found as cytoplasmic staining in all epithelial cells (arrows). (C) In the prostate a spot-like reaction is evident in the epithelial cells (arrows). The control reactions (sense probe) are shown in (B) (seminal vesicle) and (D) (prostate). Magnification: $\times 280$. 


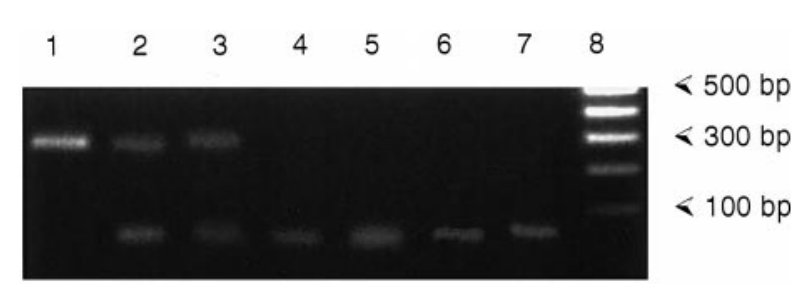

FIGURE 5. RT-PCR. Lane 1, uterus cDNA; lane 2, ovary cDNA; lane 3 , testis cDNA; lane 4 , liver cDNA; lane 5, uterus total RNA; lane 6, ovary total RNA; lane 7 , testis total RNA; lane 8,100 bp ladder.

it turned out that glycodelin mRNA expression in rat reproductive organs was restricted to epithelial cells except for the testis. These results are in accordance with those of Kämäräinen et al. (1997), who immunolocalised the glycodelin protein outside the human reproductive tract in several epithelial glands. Therefore it can be speculated that glycodelin expression is related to differentiated epithelium. On the other hand, in vitro studies on the human breast carcinoma cell line MCF-7 (Kämäräinen et al. 1997) revealed that glycodelin expression in these cells is accompanied by the acquisition of an organised glandular epithelium. This may indicate glycodelin as a differentiation factor.

The present study demonstrates the presence of glycodelin mRNA in the rat ovary. Since it is present in all healthy classes of follicular differentiation a role during normal follicular development seems to be possible. In preantral follicles the staining for glycodelin mRNA was more intense in mural granulosa cells which were close to the basement membrane compared with granulosa cells which were close to the forming antrum. Since the follicular fluid is known to be synthesised by these basal granulosa cells, it is assumed that antral fluid also contains the glycodelin protein. This hypothesis is confirmed by recent studies which have shown that glycodelin is present in human ovarian follicular fluid (Chryssikopoulos et al. 1996). Moreover, in humans, glycodelin was demonstrated in ovarian tumours and in granulosa cells of secondary follicles in the normal ovary (Kämäräinen et al. 1996).

Glycodelin levels rise during the last week of the luteal phase in the ovulatory cycle (Julkunen et al. 1986a) when progesterone levels are high. High glycodelin levels were also measured during the first days of the new cycle when progesterone levels are low. Therefore, although the glycodelin gene is possibly regulated by progesterone (by three putative progesterone/glucocorticoid response elements) (Vaisse et al. 1990) a direct correlation

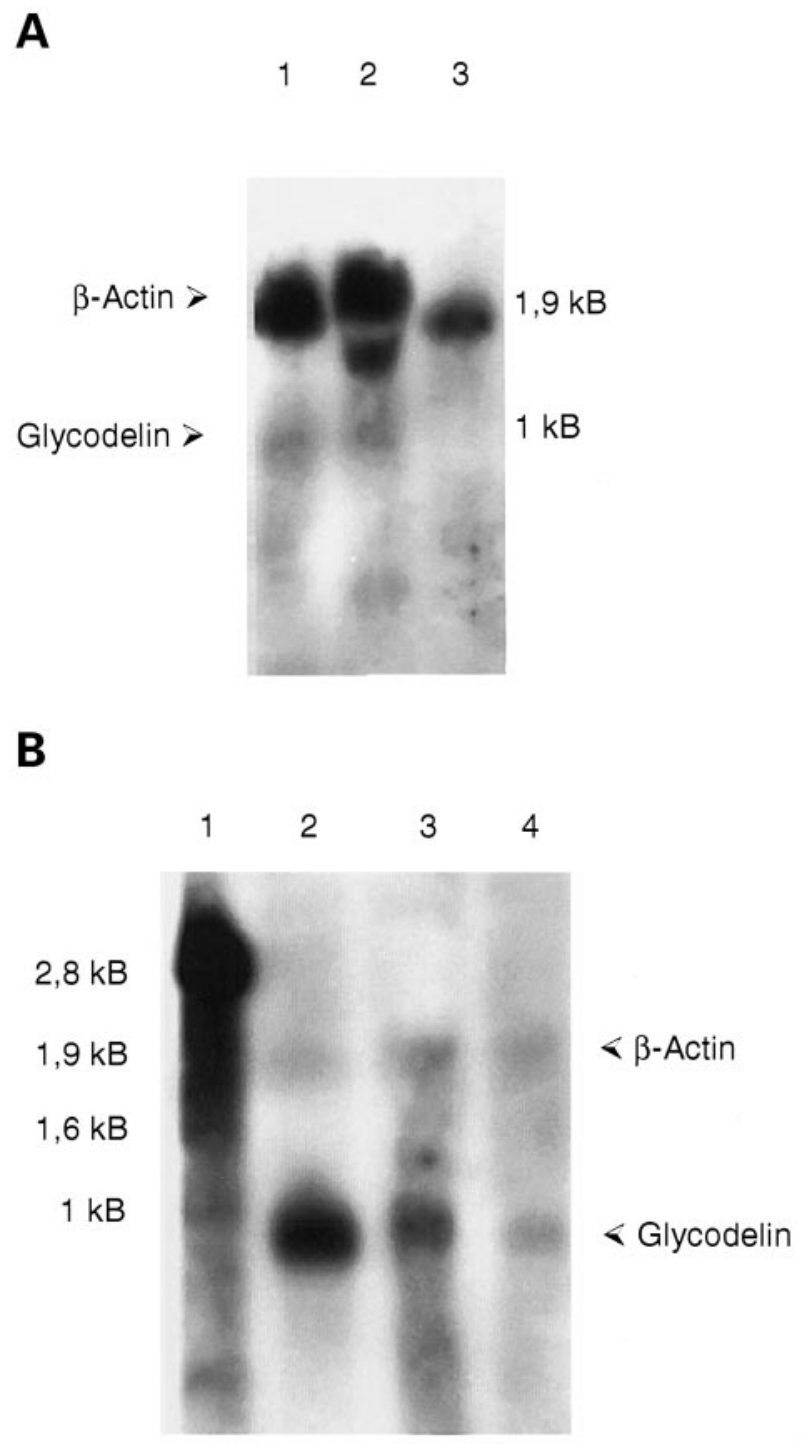

FIGURE 6. Northern blots. (A) Lane 1, rat ovary; lane 2, rat testis; lane 3, rat liver. (B) Lane 1, DIG-labelled RNA marker I; lane 2, human decidua; lane 3, human early pregnancy tissue; lane 4 , human term pregnancy tissue.

between progesterone and glycodelin seems somehow questionable. Glycodelin concentrations are very low in anovulatory women (Julkunen et al. $1986 a$ ) as well as during the follicular phase of the ovary (Fay et al. 1990). In contrast to anovulatory women during the normal menstrual cycle there is a significant glycodelin surge. This suggests that glycodelin levels depend on ovulation and the progesterone production of the corpus luteum. The true function of glycodelin in the ovary, however, remains to be elucidated. 
As in the ovary, there was no information before on the expression of glycodelin in the testis, epididymis and the prostate. In the testis a weak reaction was seen in spermatogonia as well as spermatocytes independent of the spermatogenic stage. Whether or not Sertoli cells were glycodelin mRNA positive should be additionally proven in vitro on Sertoli cell cultures. In the rat, glycodelin mRNA is also expressed in epithelial cells of the epididymis, seminal vesicle and prostate. As demonstrated previously, glycodelin is expressed in the human seminal vesicle (Julkunen et al. 1984) as well as the ampulla of the vas deferens (Koistinen et al. 1997). The secretion of the protein results in glycodelin concentrations of about $7 \%$ total protein in human seminal plasma (Julkunen et al. 1984). The regulation of the protein expression in man as well as its function is largely unknown. Since in our study glycodelin was found in epididymis, seminal vesicle and prostate as well as the testis this indicates an important function of the protein in the seminal plasma. In summary, the results obtained for uterus and seminal vesicle of rats are in accordance with previous studies on the expression of glycodelin in human tissue. In contrast, in our study we provide evidence that glycodelin mRNA is synthesised in nearly all organs of the rat reproductive tract. We propose that the rat represents a valuable model for further studying functional and physiological properties of glycodelin.

\section{ACKNOWLEDGEMENTS}

We are grateful to Prof. W Straube (Department of Obstetrics and Gynaecology, University of Greifswald) for providing the human decidua tissue, Prof. W Heinrich (Bioserv GmbH, Rostock) for generous provision of blood samples and Dr I Klöting (Institute of Pathophysiology, University of Greifswald) for supplying rats. We thank S Hanisch (Institute of Anatomy, University of Greifswald) for excellent technical assistance.

\section{REFERENCES}

Bell SC \& Doré-Green F 1987 Detection and characterization of human secretory pregnancy-associated endometrial a2-globulin in uterine luminal fluid. Fournal of Reproductive Immunology 11 13-29.

Bohn H, Kraus W \& Winckler W 1982 New soluble placental tissue proteins: their isolation, characterization, localization and quantification. In Immunology of Human Placental Proteins, pp 67-82. Ed. A Klopper. Praeger Publishers.

Bolton AE, Pockley AG, Clough KJ, Mowles EA, Stoker RJ, Westwood OMR \& Chapman MG 1987 Identification of placental protein 14 as an immunosuppressive factor in human reproduction. Lancet 1 593-595.

Chryssikopoulos A, Mantzavinos T, Kanakas N, Karagouni E, Dotsika E \& Zourlas PA 1996 Correlation of serum and follicular fluid concentrations of placental protein 14 and CA-125 in in vitro fertilization-embryo transfer patients. Fertility and Sterility 66 599-603.

Dell A, Morris HR, Panico M, Oehninger S, Patankar M, Koistinen R, Koistinen H, Seppälä M \& Clark GF 1995 Structural analysis of the oligosaccharides associated with glycodelin, a human glycoprotein with potent immunosuppressive and contraceptive activities. Fournal of Biological Chemistry $27024116-24126$.

Fay TN, Jacobs JJ, Teisner B, Westergaard JG \& Grudzinskas JG 1990 A biochemical test for the direct assessment of endometrial function: measurement of the major secretory endometrial protein PP14 in serum during menstruation in relation to ovulation and luteal function. Human Reproduction 5 382-386.

Garde J, Bell SC \& Eperon IC 1991 Multiple forms of mRNA encoding human pregnancy-associated endometrial $\alpha 2$-globulin, a $\beta$-lactoglobulin homologue. Proceedings of the National Academy of Sciences of the USA 88 2456-2460.

Julkunen M, Wahlström T, Seppälä M, Koistinen R, Koskimies A, Stenman U-H \& Bohn H 1984 Detection and localization of placental protein 14-like protein in human seminal plasma and in the male genital tract. Archives of Andrology 12 59-67.

Julkunen M, Rutanen EM, Koskimies A, Ranta T, Bohn H \& Seppälä M 1985 Distribution of placental protein 14 in tissues and body fluids during pregnancy. British Fournal of Obstetrics and Gynaecology 92 1145-1151.

Julkunen M, Apter D, Seppälä M, Stenman H \& Bohn H $1986 a$ Serum levels of placental protein 14 reflect ovulation in nonconceptional menstrual cycles. Fertility and Sterility $4547-50$.

Julkunen M, Koistinen R, Sjöberg J, Rutanen EM, Wahlström T \& Seppälä M $1986 b$ Secretory endometrium synthesizes placental protein 14. Endocrinology 118 1782-1786.

Julkunen M, Wahlström T \& Seppälä M 1986c Human fallopian tube contains placental protein 14. American Fournal of Obstetrics and Gynecology 154 1076-1079.

Julkunen M, Seppälä M \& Jänne O 1988 Complete amino acid sequence of human placental protein homologous to beta-lactoglobulin. Proceedings of the National Academy of Sciences of the USA 85 8845-8849.

Kämäräinen M, Leivo I, Koistinen R, Julkunen M, Karvonen U, Rutanen E-M \& Seppälä M 1996 Normal human ovary and ovarian tumors express glycodelin, a glycoprotein with immunosuppressive and contraceptive properties. American Fournal of Pathology 148 1435-1443.

Kämäräinen M, Seppälä M, Virtanen I \& Andersson LC 1997 Expression of glycodelin in MCF-7 breast cancer cells induces differentiation into organized acinar epithelium. Laboratory Investigation 77 565-573.

Koistinen H, Koistien R, Kämäräinen M, Salo J \& Seppälä M 1997 Multiple forms of messenger ribonucleic acid encoding glycodelin in male genital tract. Laboratory Investigation $\mathbf{7 6}$ 683-690.

Morris HR, Dell A, Easton R, Panico M, Koistinen H, Koistinen R, Oehninger S, Patankar MS, Seppälä M \& Clark GF 1996 Gender specific glycosylation of human glycodelin affects its contraceptive activities. Fournal of Biological Chemistry 271 32159-32167.

Morrow DM, Xiong N, Getty RR, Ratajczak MZ, Morgan D, Seppälä M, Riitinen L, Gewirtz AM \& Tykocinski ML 1994 An immunosuppressive factor in cells of the megakaryocytic lineage. American Fournal of Pathology 145 1485-1495. 
Oehninger S, Coddington CC, Hodgen GD \& Seppälä M 1995 Factors affecting fertilization: Endometrial placental protein 14 reduces the capacity of human spermatozoa to bind to the human zona pellicula. Fertility and Sterility $\mathbf{6 3}$ 377-382.

Saridogan E, Djahanbakhch O, Kervancioglu ME, Kahyaoglu F, Shrimanker K \& Grudzinskas JG 1997 Placental protein
14 production by human Fallopian tube epithelial cells in vitro. Human Reproduction 12 1500-1507.

Vaisse C, Atger M, Potier B \& Milgrom E 1990 Human placental protein 14 gene: sequence and characterization of a short duplication. DNA and Cell Biology 9 401-413.

REVISED MANUSCRIPT RECEIVED 15 February 1999 